University of Nebraska - Lincoln

DigitalCommons@University of Nebraska - Lincoln

Publications from USDA-ARS / UNL Faculty

U.S. Department of Agriculture: Agricultural

Research Service, Lincoln, Nebraska

January 1984

\title{
Growth Analysis Based on Degree Days
}

M. P. Russelle

USDA-ARS

Wallace Wilhelm

University of Nebraska-Lincoln, wwilhelm1@unl.edu

R. A. Olson

USDA-ARS

James F. Power

University of Nebraska-Lincoln

Follow this and additional works at: https://digitalcommons.unl.edu/usdaarsfacpub

Part of the Agricultural Science Commons

Russelle, M. P.; Wilhelm, Wallace; Olson, R. A.; and Power, James F., "Growth Analysis Based on Degree Days" (1984). Publications from USDA-ARS / UNL Faculty. 123.

https://digitalcommons.unl.edu/usdaarsfacpub/123

This Article is brought to you for free and open access by the U.S. Department of Agriculture: Agricultural Research Service, Lincoln, Nebraska at DigitalCommons@University of Nebraska - Lincoln. It has been accepted for inclusion in Publications from USDA-ARS / UNL Faculty by an authorized administrator of DigitalCommons@University of Nebraska - Lincoln. 


\title{
Growth Analysis Based on Degree Days ${ }^{1}$
}

\author{
M. P. Russelle, W. W. Wilhelm, R. A. Olson, and J. F. Power ${ }^{2}$
}

\section{ABSTRACT}

\begin{abstract}
Comparisons of growth analysis functions within and among experiments are often confounded by sources of variation other than those imposed by treatment. We suggest use of a temperature index, such as modified growing degree days, as the divisor in growth functions to facilitate treatment comparisons within certain experiments and to reduce the effects of differing temperature regimes among experiments on these comparisons. Three experiments were identified to provide data to analyze this new approach. Mean absolute growth rate (GR) and mean relative growth rate (RGR) were compared in two experiments with maize (Zea mays L.) conducted in eastern Nebraska. Previously published values of RGR and mean net assimilation rate (NAR) of barley (Hordeum vulgare L.) grown under controlled environments in a soil temperature and $P$ fertility study were also evaluated. Use of modified growing degree days, rather than days, as the divisor in these growth functions led to the recognition of physiological differences due to or associated with treatment, which were previously masked by normal crop response to temperature, and clarified other treatment differences by reducing the effect of temperature.
\end{abstract}

Additional index words: Barley, Growth functions, Growth rate, Heat units, Hordeum vulgare L., Maize, Net assimilation rate, Relative growth rate, Zea mays $\mathrm{L}$.

$\mathbf{R}$ ATES of most biological processes are affected markedly by temperature. Growth and development of whole organisms show a temperature response which results from the integrated effect of temperature on the many individual physiological processes involved.

Neild and Seeley (22) quoted the report by Reamur in 1735 that plant development was not as closely related to time as to accumulated temperature. $\mathrm{Nu}$ merous studies have demonstrated the usefulness of temperature indices, like growing degree days or heat units, for predicting crop growth and development, classifying crop species, hybrids and varieties, or evaluating climates for specific crop-management combinations $(2,7,9,11,22,25,28)$. Most proposed temperature indices show significantly greater correlation with plant growth and development than does accumulated time, although differences in the relationship among temperature indices are slight $(6,7$, $9,12,20,27)$.

Plant growth and development are certainly affected by factors other than temperature, such as flux and duration of photosynthetically active radiation, availability of nutrients and water, and loss of photosynthetic tissue. Day length plays a well-known, integral part in induction and initiation of flowering in many species (4). However, even with maize (Zea mays L.) grown under field conditions, for example, tem-

\footnotetext{
${ }^{1}$ Contribution from USDA-ARS in cooperation with the Nebraska Agric. Exp. Stn., Lincoln, Nebr. Published as Paper no. 6991, Journal Series. Received 2 Sept. 1982.

2 Soil scientist, USDA-ARS, St. Paul, Minn. (formerly assistant instructor, Dep. of Agronomy, Univ. of Nebr.-Lincoln); plant physiologist, USDA-ARS, Lincoln, Nebr.; professor, Dep. of Agronomy, Univ. of Nebr.-Lincoln, Lincoln, Nebr.; and research leader, USDA-ARS, Lincoln, Nebr.
}

perature indices alone can often explain over $95 \%$ of the variability in development $(20,22)$.

Despite general acceptance of this close relationship, the use of temperature indices has not been generally extended to growth analysis. Growth analysis has been a valuable tool in the quantitative analysis of plant and crop growth since the suggestion by Blackman in 1919 (5) that growth generally follows the compound interest law. He used absolute growth rate $(\overline{\mathrm{GR}})$, relative growth rate $(\overline{\mathrm{RGR}})$, leaf area ratio $(\overline{\mathrm{LAR}})$, net assimilation rate $(\overline{\mathrm{NA}} \overline{\mathrm{R}})$, and other similar functions to describe plant growth. Growth analysis can be approached on an individual plant or areal basis.

The growth functions, $\overline{\mathrm{GR}}, \overline{\mathrm{RGR}}$, and $\overline{\mathrm{NAR}}$, increase with temperature and light flux within a range specific for a given crop $(29,30,31)$. Growth functions calculated in the traditional manner will necessarily include the effect of controlled and uncontrolled environmental variables.

The purpose of calculating growth functions is generally to describe or explain how one or more plant species respond to a given environmental situation. In many experiments, environmental conditions will vary considerably among years and will vary within any one year for different treatments, such as planting date or location. These environmental variables confound comparisons of growth functions for crops having the same treatment regime over two or more years or for crops having different treatments in the same season. Calculations based on time may be appropriate for an experiment as long as it is recognized that environmental conditions are confounded with species and treatment. However, in experiments designed to make comparisons of physiological response, growth functions ideally should be independent of environmental variables. Comparisons of growth functions within and among different experiments would be less ambiguous if sources of variation other than imposed treatments could be eliminated.

We suggest that growth analysis functions be calculated using a temperature index as the divisor, rather than using time. In a survey of growth analysis literature $(1,8,10,13,15,18,24,26,32,33)$, we found only three references in which a temperature index was used to calculate growth rate. Hawkins and Cooper (15) calculated $\overline{G R}$ as $\mathrm{g}_{\text {plant }}{ }^{-1} \mathrm{Cd}^{-1}$, where Cd was the product of days and average daily air temperature above a base of $9^{\circ} \mathrm{C}$. Grain $\overline{\mathrm{GR}}$ was based on a temperature index in two articles $(1,8)$. Our suggested approach is to define

$$
\overline{\mathrm{GR}}_{\mathrm{M}}=\left(\mathrm{W}_{2}-\mathrm{W}_{1}\right) /\left(\mathrm{M}_{2}-\mathrm{M}_{1}\right)
$$

and

$$
\overline{\mathbf{R G R}}_{\mathbf{M}}=\left(\log _{\mathrm{e}} \mathrm{W}_{\mathbf{2}}-\log _{\mathrm{e}} \mathrm{W}_{1}\right) /\left(\mathbf{M}_{2}-\mathrm{M}_{1}\right) \text {, }
$$

where $W_{1}$ and $W_{2}$ are dry weights of plant samples at two successive sampling times, and $M_{1}$ and $M_{2}$ are 
a temperature index, such as modified growing degree days, from some common date such as planting or emergence to the respective dates of sampling. Growth analysis formulae calculated in this manner should be designated by the subscript "M" for modified growing degree days to differentiate them from time-based formulae. The $\overline{\mathrm{NAR}}_{\mathrm{M}}$ should be calculated only after establishing the relationships between leaf area (A) and dry weight (W), since the appropriate form of the equation depends upon this relationship (24). However, the chosen temperature index would be used as the divisor. The objective of this paper is to demonstrate the use of temperature index as opposed to time as the divisor in growth analysis functions, using data from three previously completed experiments.

\section{MATERIALS AND METHODS}

To show the effect of using a temperature index rather than time in the calculation of growth functions, we applied standard analyses of variance to data from two field experiments conducted in eastern Nebraska by the authors, both involving maize. Experiment $I$ was conducted near Lincoln, Nebr., on a Butler silty clay loam (fine, montmorillonitic, mesic Abruptic Argiaquolls) on rain-fed maize (cv. Neb 620) planted in each of 2 years on plots subjected to three different combinations of tillage and manure application. All plots received a uniform application of $70 \mathrm{~kg}$ $\mathrm{N} \mathrm{ha}{ }^{-1}$ as $\mathrm{NH}_{4} \mathrm{NO}_{3}$ and were replicated four times. Plant samples (four from each replication) were procured from each treatment for dry matter determination at 5-leaf, 11 to 12-leaf, blister, hard-dough, and physiological maturity stages in 1977, and 4-leaf, 12- to 13-leaf, blister, hard-dough, and physiological maturity stages in 1979. Experiment II was conducted near Mead, Nebr., on a Sharpsburg silty clay loam (fine, montmorillonitic, mesic Typic Argiudolls) and included early and late planting (late April and late May 1980, respectively) of irrigated maize (cv. Neb 714) with a factorial combination of two $\mathrm{N}$ rates at four application times. Three plants from each of four replications were sampled at 8-leaf, 12-leaf, silking, soft-dough, and physiological maturity [stages $2,3,5,7$, and 10 , respectively (14)]

Aboveground dry weights were determined for individual plants after drying at $70^{\circ} \mathrm{C}$, and calculations of $\overline{G R}$, $\overline{\mathbf{R G R}}, \overline{\mathbf{G R}}_{\mathrm{M}}$, and $\overline{\mathbf{R G R}}_{\mathrm{M}}$ were made for both experiments. Standard analyses of variance were computed for all functions. In Exp. I, treatments were sampled on the same date, so only the comparisons of growth functions between years are discussed here. In Exp. II, all $\mathbf{N}$ treatments within a planting date were sampled at the same time, so conversion of $\overline{G R}$ and $\overline{R G R}$ to $\overline{G R}_{M}$ and $\overline{R G R}_{M}$, respectively, did not change these comparisons. Because differences between the analyses were statistically significant only between planting dates, only these means are examined here.

Also evaluated were data published by Power et al. (23) on barley (Hordeum vulgare L.) grown in controlled environment chambers on Parshall fine sandy loam (coarseloamy, mixed Pachic Haploborolls) topsoil at two P fertilization rates $\left(8.8\right.$ and $\left.44.0 \mathrm{mg} P \mathrm{~kg}^{-1}\right)$, constant air temperature $\left(22^{\circ} \mathrm{C}\right)$, and constant soil temperatures of $9.0,15.5$, or $22.0^{\circ} \mathrm{C}$ (Exp. III). Dry-matter and leaf-area determinations were made at the 3-leaf, 4-leaf, tillered, headed, soft-dough, and maturity stages [corresponding to stages 1 to 6, respectively (23)]. The $\overline{\mathrm{NAR}}$ and $\mathrm{RGR}$, calculated by
Table 1. Values of $\overline{\mathbf{G R}}$ and $\overline{\mathrm{RGR}}$, calculated on the basis of days (d), and $\overline{G R}_{M}$ and $\overline{\mathbf{R G R}}_{\mathbf{M}}$, calculated on the basis of modified growing degree days (M), for the indicated intervals between growth stages for tillage experiment with maize at Lincoln, Nebr. (Exp. I).

\begin{tabular}{|c|c|c|c|c|c|c|c|c|c|c|}
\hline \multirow[b]{3}{*}{ Year } & \multicolumn{5}{|c|}{ Day basis } & \multicolumn{5}{|c|}{ Growing degree day basis } \\
\hline & \multicolumn{10}{|c|}{ Growth stage interval $\dagger$} \\
\hline & $0-1$ & $1-3$ & $3-6$ & $6-8$ & $8-10$ & $0-1$ & $1-3$ & $3-6$ & $6-8$ & $8-10$ \\
\hline & \multicolumn{5}{|c|}{$\widehat{\mathrm{GR}}$} & \multicolumn{5}{|c|}{$\begin{array}{c}\overline{\mathrm{GR}}_{\mathrm{M}} \\
\mathrm{kg} \mathrm{ha}^{-1} \mathrm{M}\end{array}$} \\
\hline $\begin{array}{l}1977 \\
1979 \\
\text { Signi- } \\
\text { ficance }\end{array}$ & $\begin{array}{l}19 \\
19\end{array}$ & $\begin{array}{c}143 \\
196 \\
*\end{array}$ & $\begin{array}{r}72 \\
221 \\
* \\
\text { RGR }\end{array}$ & $\begin{array}{r}65 \\
221 \\
*\end{array}$ & $\begin{array}{c}-19 \\
104 \\
*\end{array}$ & $\begin{array}{l}1.7 \\
1.8\end{array}$ & $\begin{array}{c}10.3 \\
14.8 \\
*\end{array}$ & $\begin{array}{r}4.9 \\
17.1 \\
* \\
\overline{R G R}_{M}\end{array}$ & $\begin{array}{r}5.1 \\
16.6 \\
*\end{array}$ & $\begin{array}{r}-1.7 \\
8.4 \\
*\end{array}$ \\
\hline $\begin{array}{l}1977 \\
1979 \\
\text { Signi- } \\
\quad \text { ficance }\end{array}$ & $\begin{array}{l}7 \\
7\end{array}$ & $\begin{array}{l}82 \\
75 \\
*\end{array}$ & $\begin{array}{l}18 \\
28 \\
*\end{array}$ & $\begin{array}{r}9 \\
17 \\
*\end{array}$ & $\begin{array}{r}-5 \\
8 \\
* \\
\text { Divi }\end{array}$ & $\begin{array}{l}0.6 \\
0.6\end{array}$ & $\begin{array}{l}6.0 \\
5.6\end{array}$ & $\begin{array}{l}1.2 \\
2.1 \\
*\end{array}$ & $\begin{array}{l}0.7 \\
1.3\end{array}$ & $\begin{array}{r}-0.4 \\
0.6 \\
\\
*\end{array}$ \\
\hline $\begin{array}{l}1977 \\
1979\end{array}$ & $\begin{array}{l}42 \\
44\end{array}$ & $\begin{array}{l}17 \\
27\end{array}$ & $\begin{array}{l}28 \\
22\end{array}$ & $\begin{array}{l}18 \\
14\end{array}$ & $\begin{array}{l}20 \\
14\end{array}$ & $\begin{array}{l}480 \\
468\end{array}$ & $\begin{array}{l}235 \\
358\end{array}$ & $\begin{array}{l}417 \\
285\end{array}$ & $\begin{array}{l}232 \\
186\end{array}$ & $\begin{array}{l}230 \\
174\end{array}$ \\
\hline
\end{tabular}

* Differences between means for years within an interval significant at $P<0.05$.

$\dagger$ Approximate growth stages (see text), following notation of Hanway (14). $\ddagger$ Divisors used to calculate functions for each interval.

the original authors on a time basis, were compared with $\overline{\mathrm{NAR}}_{\mathrm{M}}$ and $\overline{\mathrm{RGR}}_{\mathrm{M}}$.

The temperature index chosen was modified growing degree days (12), which was calculated from date of planting or emergence to the date of sampling by summing the following value for each day

$$
M=\left[\left(T_{\max }+T_{\min }\right) / 2\right]-T_{B},
$$

where $M$ was the degree days for a given day, $T_{\max }$ was the maximum daily air temperature with an upper limit of $30^{\circ} \mathrm{C}$, $\mathrm{T}_{\min }$ was the minimum daily air temperature with a lower limit of $10^{\circ} \mathrm{C}$, and $\mathrm{T}_{\mathrm{B}}$ was equal to $10^{\circ} \mathrm{C}$ for Exp. I and 11 . Air temperatures were recorded for nearby U.S. Weather Bureau stations at the Lincoln Municipal Airport and the Mead Agronomy Laboratory for Exp. I and II, respectively. This index was very closely related to maize development until silking $\left(\mathrm{r}^{2}=0.98, \mathrm{P}<0.01\right)$. In Exp. III, soil temperature was used instead of air temperature. Because air temperature was constant throughout the experiment, daily $M=T_{S}-T_{B}$, where $T_{S}$ was the soil temperature (9.0, 15.5 , or $22.0^{\circ} \mathrm{C}$ ), and $T_{B}$ was $5^{\circ} \mathrm{C}(21)$. Inspection of the resulting values made it clear that a maximum limit to the average $T_{s}$ was required. This limit was set at $10^{\circ} \mathrm{C}$ for reasons given in the next section.

\section{RESULTS AND DISCUSSION}

In Exp. I, yearly differences between $\overline{\mathrm{GR}}$ and $\overline{\mathbf{G R}}_{\mathrm{M}}$ were similar (Table 1). The significantly lower growth rates during 1977 compared to 1979 resulted from extreme drought during the 1976 growing season (May to September precipitation 45\% below normal), little precipitation during the 1976 to 1977 winter (October to April, 29\% below normal), and only one rainfall event greater than $25 \mathrm{~mm}$ in the 40 days prior to tasseling in 1977. Although water stress limited $\overline{\mathrm{GR}}$ and $\overline{\mathrm{GR}}_{\mathrm{M}}$ during 1977, the comparison of $\overline{\mathrm{RGR}}$ 
Table 2. Values of GR and $\overline{\mathbf{R G R}}$, calculated on the basis of days, and $\overline{\mathbf{G R}}_{\mathrm{M}}$ and $\overline{\mathbf{R G R}}_{\mathrm{M}}$, calculated on the basis of modified growing degree days (M), for the indicated intervals between growth stages for planting date experiment with maize at Mead, Nebr., 1980 (Exp. II).

\begin{tabular}{|c|c|c|c|c|c|c|c|c|c|c|}
\hline \multirow[b]{3}{*}{ Planting date } & \multicolumn{5}{|c|}{ Day basis } & \multicolumn{5}{|c|}{ Growing degree day basis } \\
\hline & \multicolumn{10}{|c|}{ Growth stage interval } \\
\hline & $0-2$ & $2-3$ & $3-5$ & $5-7$ & $7-10$ & $0-2$ & $2-3$ & $3-5$ & $5-7$ & $7-10$ \\
\hline \multirow{3}{*}{$\begin{array}{l}\text { Early } \\
\text { Late } \\
\text { Significance }\end{array}$} & \multicolumn{5}{|c|}{$\begin{array}{c}\overline{\mathrm{GR}} \\
\text { g plant } \\
\text { payy }^{-1}\end{array}$} & \multicolumn{5}{|c|}{$\begin{array}{c}\overline{\mathrm{G}} \overline{\mathrm{R}}_{\mathrm{M}} \\
\text { g plant }^{-1} \mathbf{M}^{-1}\end{array}$} \\
\hline & $\begin{array}{c}0.32 \\
0.48 \\
*\end{array}$ & $\begin{array}{l}2.88 \\
2.76\end{array}$ & $\begin{array}{l}4.42 \\
4.23\end{array}$ & $\begin{array}{c}4.78 \\
3.97 \\
*\end{array}$ & $\begin{array}{c}5.59 \\
2.57 \\
*\end{array}$ & $\begin{array}{c}0.036 \\
0.041 \\
*\end{array}$ & $\begin{array}{c}0.232 \\
0.193 \\
*\end{array}$ & $\begin{array}{c}0.301 \\
0.281 \\
*\end{array}$ & $\begin{array}{c}0.338 \\
0.290 \\
\dagger\end{array}$ & $\begin{array}{c}0.400 \\
0.213 \\
*\end{array}$ \\
\hline & & & $\overline{\mathbf{R G R}}$ & & & & & $\overline{\mathrm{RGR}}_{\mathrm{M}}$ & & \\
\hline \multirow[t]{2}{*}{$\begin{array}{l}\text { Early } \\
\text { Late } \\
\text { Significance }\end{array}$} & $\begin{array}{l}72 \\
92 \\
*\end{array}$ & $\begin{array}{l}100 \\
100\end{array}$ & $\begin{array}{l}49 \\
53\end{array}$ & $\begin{array}{l}25 \\
24\end{array}$ & $\begin{array}{c}14 \\
10 \\
+\end{array}$ & $\begin{array}{l}7.6 \\
8.3 \\
*\end{array}$ & $\begin{array}{l}9.1 \\
7.4 \\
*\end{array}$ & $\begin{array}{l}3.5 \\
3.5\end{array}$ & $\begin{array}{l}1.8 \\
1.7\end{array}$ & $\begin{array}{l}1.3 \\
0.8 \\
*\end{array}$ \\
\hline & \multicolumn{10}{|c|}{ Divisor $\S$} \\
\hline $\begin{array}{l}\text { Early } \\
\text { Late }\end{array}$ & $\begin{array}{l}36 \\
28\end{array}$ & $\begin{array}{l}16 \\
13\end{array}$ & $\begin{array}{l}17 \\
17\end{array}$ & $\begin{array}{l}25 \\
25\end{array}$ & $\begin{array}{l}20 \\
28\end{array}$ & $\begin{array}{l}322 \\
325\end{array}$ & $\begin{array}{l}199 \\
186\end{array}$ & $\begin{array}{l}250 \\
256\end{array}$ & $\begin{array}{l}353 \\
343\end{array}$ & $\begin{array}{l}279 \\
335\end{array}$ \\
\hline
\end{tabular}

*, $†$ Differences between means for years within an interval significant at $P<0.05$ and $P<0.10$, respectively.

$\$$ Approximate growth stages (see text), following notation of Hanway (14).

$\$$ Divisors used to calculate functions for each interval.

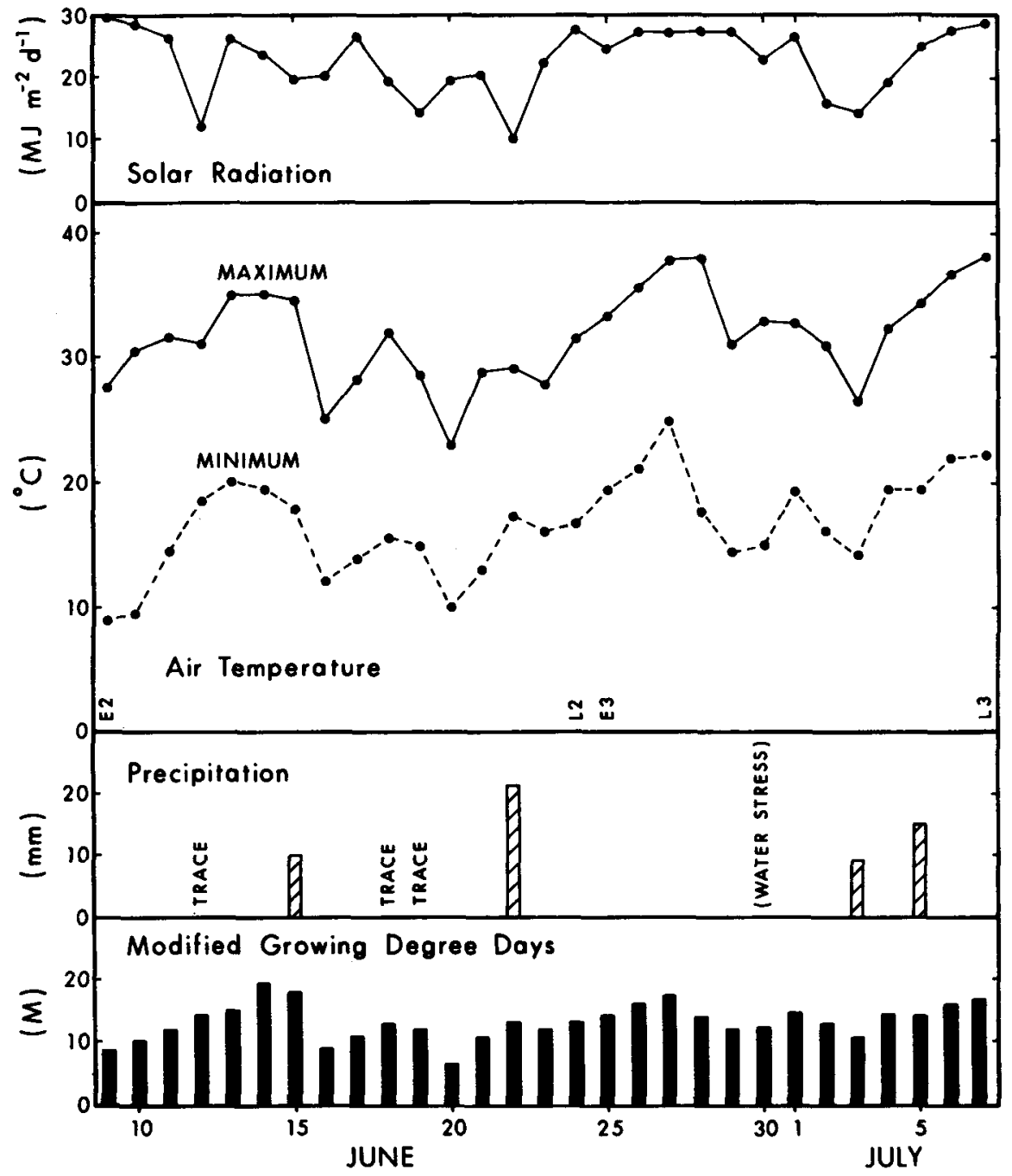

Fig. 1. Meteorological data and growth stage observations from 9 June to 6 July 1980 for Exp. I1. The symbols, E2, L2, E3, and L3, indicate the dates when early- and late-planted maize reached growth stages 2 and 3 (8- and 12-leaf, respectively). 
Table 3. Values of $\overline{\mathbf{R G R}}$ and $\overline{\mathbf{R G R}}_{\mathrm{M}}$, calculated on the basis of days and modified growing degree days (M), respectively, at specific growth stage intervals for barley grown in a controlled environment experiment (air temperature constant at $22^{\circ} \mathrm{C}$ ) with three levels of soil temperature (23) (Exp. III).

\begin{tabular}{|c|c|c|c|c|c|c|c|c|c|c|c|c|c|c|c|}
\hline \multirow{3}{*}{$\begin{array}{c}\text { Soil } \\
\text { temperature }\end{array}$} & \multicolumn{5}{|c|}{ Day basis } & \multicolumn{10}{|c|}{ Growing degree day basis } \\
\hline & \multicolumn{15}{|c|}{ Growth stage interval $\dagger$} \\
\hline & $1-2$ & $2-3$ & $3-4$ & $4-5$ & $5-6$ & $1-2$ & $2-3$ & $3-4$ & $4-5$ & $5-6$ & $1-2$ & $2-3$ & 3-4 & $4-5$ & $5-6$ \\
\hline \multirow[t]{3}{*}{${ }^{\circ} \mathrm{C}$} & \multirow{2}{*}{\multicolumn{5}{|c|}{$\overline{\overline{\mathbf{R G R}}}$}} & \multicolumn{10}{|c|}{$\overline{\mathrm{RGR}}_{\mathrm{M}}$} \\
\hline & & & & & & \multicolumn{5}{|c|}{ No upper limit§ } & \multicolumn{5}{|c|}{$10^{\circ} \mathrm{C}$ upper limit } \\
\hline & \multicolumn{5}{|c|}{$\mathbf{g ~ k g}^{-1} \mathrm{day}^{-3}$} & & & & & \multicolumn{2}{|c|}{$\mathrm{g} \mathrm{kg}^{-1} \mathbf{M}^{-1}$} & & & & \\
\hline 9.0 & 104 & 88 & 38 & 38 & 13 & 26 & 22 & 10 & 10 & 3 & 26 & 22 & 10 & 10 & 3 \\
\hline 15.5 & 143 & 123 & 51 & 24 & 0 & 13 & 12 & 5 & 2 & 0 & 29 & 25 & 10 & 5 & 0 \\
\hline \multirow[t]{2}{*}{22.0} & 172 & 122 & 51 & 20 & 0 & 10 & 7 & 3 & 1 & 0 & 34 & 24 & 10 & 4 & 0 \\
\hline & \multicolumn{15}{|c|}{ Divisorł } \\
\hline 9.0 & 6 & 19 & 22 & 9 & 20 & 24 & 76 & 88 & 36 & 80 & 24 & 76 & 88 & 36 & 80 \\
\hline 15.5 & 4 & 14 & 21 & 17 & 13 & 42 & 147 & 221 & 179 & 137 & 20 & 70 & 105 & 80 & 61 \\
\hline 22.0 & 3 & 12 & 26 & 17 & 13 & 51 & 204 & 442 & 289 & 221 & 15 & 60 & 130 & 80 & 61 \\
\hline
\end{tabular}

† Growth stage as defined by (23).

$\ddagger$ Divisors used to calculate functions for each interval.

$\S \mathrm{M}=\mathrm{T}_{\mathrm{S}}-\mathrm{T}_{\mathrm{B}}, \mathrm{T}_{\mathrm{B}}=5^{\circ} \mathrm{C}$.

I $M=T_{S}-T_{B}, T_{B}=5^{\circ} \mathbf{C}, T_{S} \leq 10^{\circ} \mathbf{C}$.

and $\overline{\mathrm{RGR}}_{M}$ indicated the use of $M$ as the divisor accounted for differences in growth between the 2 years during some of the growth stage intervals (1 to 3 and 6 to 8). This suggested that variation in environmental factors other than temperature limited $\overline{\mathbf{R G R}}_{\mathbf{M}}$ during tasseling (growth stage interval 3 to 6) and late grain filling (growth stage interval 8 to 10). As indicated above, water stress likely reduced growth during growth stage interval 3 to 6 .

Significant differences in Exp. II were present in several comparisons of $\overline{\mathbf{G R}}_{\mathrm{M}}$ and $\overline{\mathrm{RGR}}_{\mathrm{M}}$, but were evident in only a few comparisons of $\overline{G R}$ and $\overline{R G R}$ (Table 2). Differences between effects of planting date on mean absolute growth rate for growth stage intervals 2 to 3 and 3 to 5 became apparent only after accounting for differences in temperature. In only one case (growth stage interval 5 to 7 ) was the effect of planting date upon $\overline{\mathrm{GR}}$ significant while $\overline{\mathrm{GR}}_{\mathrm{M}}$ was not $(p=0.05)$. The similarity among the $M$ divisors for each planting is striking in comparison with the initial disparity among days. Delayed recognition of black layer formation in the late planting may have been partly responsible for the differences in day and $M$ for the final interval.

Let us examine the period from stage 2 to 3 in Exp. II more closely. The early and late plantings did not exhibit different $\overline{\mathrm{GR}}$ and $\overline{\mathrm{RGR}}$, but both $\overline{\mathrm{GR}}_{\mathrm{M}}$ and $\overline{R G R}_{M}$ were different (Table 2). Which comparison is more informative? The late planting reached the third growth stage 3 days faster than the early planting, but $M$ was very similar. Maximum and minimum air temperatures were about 3 and $5^{\circ} \mathrm{C}$ higher, respectively, and average solar photosynthetic photon flux density was higher (24.6 vs. $22.2 \mathrm{MJ} \mathrm{m} \mathrm{m}^{-2}$ day $^{-1}$ ) from 24 June to 7 July than from 9 to 25 June (Fig. 1). These conditions might be expected to increase rate of dry-matter accumulation in the late planting compared to the early planting during development from stage 2 to 3 ; however, all plants appeared water stressed in the afternoon of 30 June. (The maize could have exhibited water stress on other days from 26 June through 2 July, but no other ob- servations were made). Water stress is known to reduce dry-matter accumulation in maize (16), but more rapid (daily) phenological development of the lateplanted crop masked this effect. Therefore, the temperature index-based growth function seemed to more accurately reflect the growth rates exhibited in the field.

The comparison of days and $M$ as divisors in growth function calculations in Exp. III was dramatic when no upper limit was set for soil temperature, and resulted in a complete reversal in pattern of $\overline{\mathbf{R G R}}_{\mathbf{M}}$ (Table 3). According to the general concept of growing degree days, total $M$ between specific stages of development should not vary significantly with temperature. Very large differences in total $M$ between similar stage at different temperature treatments were obtained when $\mathbf{T}_{\mathbf{S}}$ was not limited. Barley grown at $9.0^{\circ} \mathrm{C}$ required $368 \mathrm{M}$ to reach maturity after transplanting [i.e., with $\mathrm{T}_{\mathrm{B}}=5^{\circ} \mathrm{C}, 92$ days $\times 4^{\circ} \mathrm{C}(23)$ ]. Barley required only 78 days to mature at both higher temperatures. The disparity in total $\mathrm{M}$ among temperatures can be alleviated by setting the upper limit of $T_{S}$ at $10^{\circ} \mathrm{C}$ [i.e., $(368 \mathrm{M} / 78$ days $)+T_{B}$, rounded to $10^{\circ} \mathrm{C}$ for calculations]. Need for a correction for excessive soil temperature appeared to be justified by the final dry-matter production, which was $17.2,18.3$, and $15.4 \mathrm{~g} \mathrm{pot}^{-1}$ for $9.0,15.5$, and $22.0^{\circ} \mathrm{C}$, respectively. This trend would also suggest a limit for $T_{S}$ between 9.0 and $15.5^{\circ} \mathrm{C}$. In contrast, maize dry matter accumulation tended to decrease at soil temperatures greater than $15.0^{\circ} \mathrm{C}(3)$.

Statistical evaluation of the $\overline{R G R}$ and $\overline{\mathrm{RGR}}_{\mathrm{M}}$ values was not possible because only treatment means were reported by the authors (23). Temperature did not affect $\overline{N A R}$, but use of $\overline{N A R}_{M}$ decreased the ratio of high to low values across temperature treatment and maintained the ratio across $P$ treatments (Table 4). These results clearly indicate the value of our approach.

For simplicity, only temperature was included in our calculations. Measurements of light flux and duration, though easy to make with modern instru- 
Table 4. Values of $\overline{\mathrm{NAR}}$ and $\overline{\mathrm{NAR}}$, calculated on the basis of days and modified growing degree days (M), respectively, for the growth intervals from heading to soft-dough (Exp. III).

\begin{tabular}{|c|c|c|c|c|}
\hline \multirow{3}{*}{$\begin{array}{c}\text { Soil } \\
\text { temperature } \\
\left({ }^{\circ} \mathrm{C}\right)\end{array}$} & \multicolumn{4}{|c|}{ P fertilization rate ( $\mathrm{mg} \mathrm{P} \mathrm{kg}{ }^{-1}$ soil) } \\
\hline & 8.8 & 44.0 & 8.8 & 44.0 \\
\hline & \multicolumn{2}{|c|}{$\overline{\mathbf{N A R}}$} & \multicolumn{2}{|c|}{$\overline{\mathbf{N A R}} \overline{\mathbf{M}}^{\dagger}$} \\
\hline & \multicolumn{2}{|c|}{$-\mathrm{g} \mathrm{m}^{-2}$ day } & \multicolumn{2}{|c|}{$\mathrm{g} \mathrm{m}^{-2} \mathrm{M}$} \\
\hline 9.0 & 6.8 & 10 & 1.7 & 2.6 \\
\hline 15.5 & 9.0 & 18 & 1.9 & 3,8 \\
\hline 22.0 & 9.5 & 12 & 2.0 & 2.4 \\
\hline
\end{tabular}

$\dagger M=T_{S}-T_{B}, T_{B}=5^{\circ} \mathrm{C}, T_{S} \leq 10^{\circ} \mathrm{C}$.

mentation, are not available for most published experiments. Air temperature data are usually available from weather stations maintained at most experiment stations or may be derived from information given in the materials and methods section of growth chamber studies, thereby facilitating this suggested method of calculation of growth functions from published experiments.

The choice of a particular temperature index as the divisor in growth functions will depend on the availability and type of temperature data and on the cardinal temperatures for the crop in question. It is important to use an index which is defined for the reader, is more closely related than time to observed plant growth, and includes well estimated cardinal temperatures. Use of $M$ as the divisor in growth functions should not increase experimental error, if this procedure is followed. The coefficients of variation associated with the traditional and proposed methods of calculation were within 2 percentage points of each other in Exp. I and II (data not shown). It is preferable to use canopy temperatures to air temperatures, when the former are available.

Use of a temperature index as the divisor in growth analysis formulae is not limited to sampling at predetermined growth stages or to comparisons of mean growth functions within an experiment. Continuous functions could be calculated with a temperature index using regression analysis $(17,19)$. Because of the close relationship between temperature and crop development, the use of a temperature index in these formulae should make comparisons among and within experiments more meaningful. We anticipate that use of this method may lead to the recognition of physiological responses to treatment previously masked by normal (and expected) crop response to changing temperature.

\section{REFERENCES}

1. Andersen, K., and S. Andersen. 1981. Increase in dry matter and decrease in moisture content during ripening of barley. Acta Agric. Scand. 31:70-74.

2. Anstey, T.H. 1966. Prediction of full bloom date for apple, pear, cherry, peach, and apricot from air temperature data. Am. Soc. Hortic. Sci. Proc. 88:57-66.

3. Beauchamp, E.C., and D.J. Lathwell. 1967. Effect of changes in root zone temperature on the subsequent growth and development of young corn plants. Agron. J. 59:189-193.

4. Bidwell, R.G.S. 1974. Plant physiology. Macmillan Publishing Co., Inc., New York.

5. Blackman, V.H. 1919. The compound interest law and plant growth. Ann. Bot. 33:353-360.
6. Coelho, D.T., and R.F. Dale. 1980. An energy-crop growth variable and temperature function for predicting corn growth and development: planting to silking. Agron. J. 72:503-510.

7. Crane, P.L., P.R. Goldsworthy, R.L. Cuany, M.S. Zuber, and C.A. Francis. 1977. Climatological factors in maize adaptation. p. 49-56. In Agrometeorology of the maize (corn) crop. Proc. Symp. World Meteorol. Organiz., Ames, Iowa. WMO No. 481 .

8. Crosbie, T.M., and J.J. Mock. 1981. Changes in physiological traits associated with grain yield improvements in three maize breeding programs. Crop Sci. 21:255-259.

9. Cross, H.Z., and M.S. Zuber. 1972. Prediction of flowering dates in maize based on different methods of estimating thermal units. Agron. J. 64:351-355.

10. Evans, G.C. 1972. The quantitative analysis of plant growth. Blackwell Scientific Pub., Oxford.

11. Fairey, N.A. 1983. Yield, quality and development of forage maize as influenced by dates of planting and harvesting. Can. J. Plant Sci. 63:157-168.

12. Gilmore, E.C., Jr., and J.S. Rogers. 1958. Heat units as a method of measuring maturity in corn. Agron. J. 50:611-615.

13. Hammond, L.C., and Don Kirkham. 1949. Growth curves of soybeans and corn. Agron. J. 41:23-29.

14. Hanway, J.J. 1963. Growth stages of corn (Zea mays L.). Agron. J. 55:487-492.

15. Hawkins, R.C., and P.J.M. Cooper. 1981. Growth, development and grain yield of maize. Exp. Agric. 17:203-207.

16. Hsaio, T.C. 1973. Plant responses to water stress. Ann. Rev. Plant Physiol. 24:519-570.

17. Hughes, A.P., and P.R. Freeman. 1967. Growth analysis using frequent small harvests. J. Appl. Ecol. 4:553-560.

18. Hunt, Roderick. 1978. Plant growth analysis. The Inst. of Biol. Studies in Biol. No. 96. Edward Arnold, London.

19. - - , and I.T. Parsons. 1974. A computer program for deriving growth-functions in plant growth-analysis. J. Appl. Ecol. 11:297-307.

20. Kiniry, J.R., and M.E. Keener. 1982. An enzyme kinetic equation to estimate maize development rates. Agron. J, 74:115119.

21. Lallukka, U., O. Rantanen, and J. Mukula. 1978. The temperature sum requirements of barley varieties in Finland. Ann. Agric. Fenn. 17:185-191.

22. Neild, R.E., and M.W. Seeley. 1977. Growing degree days predictions for corn and sorghum development and some applications to crop production in Nebraska. Nebr. Agric. Exp. Stn. Res. Bull. 280. Lincoln, Nebr.

23. Power, J.F., W.O. Willis, D.L. Grunes, and G.A. Reichman. 1967. Effect of soil temperature, phosphorus, and plant age on growth analysis of barley. Agron. J. 59:231-234.

24. Radford, P.J. 1967. Growth analysis formulae-their use and abuse. Crop Sci. 7:171-175.

25. Shaw, R.H. 1975. Growing-degree-units for corn in the North Central Region. North Central Regional Res. Publ. No. 229. Iowa Agric. Exp. Stn. Res. Bull. 581. Ames, Iowa.

26. Stuff, R.G., H.F. Hodges, R.F. Dale, W.E. Nyquist, W.L. Nelson, and K.L. Scheeringa. 1979. Measurement of short-period corn growth. Purdue Univ. Agric. Exp. Stn. Res. Bull. 961. West Lafayette, Ind.

27. Tollenaar, M., T.B. Daynard, and R.B. Hunter. 1979. Effect of temperature on rate of leaf appearance and flowering date in maize. Crop Sci. 19:363-366.

28. Tscheschke, P.D., and J.R. Gilley. 1979. Status and verification of Nebraska's corn growth model-CORNGRO. Trans. Am. Soc. Agric. Eng. 22:1329-1337.

29. Voldeng, H.D., and G.E. Blackman. 1973a. The influences of seasonal changes in solar radiation and air temperature on the growth in the early vegetative phase of Zea mays. Ann. Bot. 37:553-563.

30. development and seasonal changes in light and temperature on the components of growth in Zea mays. Ann. Bot. 37:895904.

31. Watson, D.J. 1952. The physiological basis of variation in yield. Adv. Agron. 4:101-145.

32. - 1968. A prospect of crop physiology. Ann. Appl. Biol. 62:1-9.

33. Williams, R.F. 1975. The quantitative description of growth. p. 9-26. In The shoot apex and leaf growth. Cambridge Unjv Press, London. 